\title{
Aphaereta sp. (HYMENOPTERA: BRACONIDAE: ALYSIINAE) AS A NATURAL ENEMY TO Peckia chrysostoma (WIEDEMANN) (DIPTERA: SARCOPHAGIDAE), IN BRAZIL
}

\author{
MARCHIORI, C. H., PEREIRA, L. A. and FILHO, O. M. S. \\ Instituto Luterano de Ensino Superior de Itumbiara-ILES-ULBRA, Avenida Beira Rio, 1001, \\ C.P. 23-T, CEP 75500-000, Itumbiara, Goiás, Brazil \\ Correspondence to: Carlos Henrique Marchiori, Departamento de Ciências Naturais do Instituto Luterano de \\ Ensino Superior de Itumbiara-ILES-ULBRA, Avenida Beira Rio, 1001, C.P. 23-T, CEP 75500-000, \\ Itumbiara, Goiás, Brazil, e-mail: pesquisa.itb@ulbra.br \\ Received December 4, 2001 - Accepted March 5, 2002 - Distributed February 28, 2003
}

(With 2 figures)

\begin{abstract}
This paper reports the first occurence of the parasite Aphaereta sp. (Hymenoptera: Braconidae: Alysiinae) which was collected from Peckia chrysostoma pupae (Diptera: Sarcophagidae) by means of traps containing some fish baits in a wood area close to the Agronomy college (Faculdade of Agronomia) in Itumbiara, Goiás, in the period from March to September, 2001. A total of 362 gregarious specimens of parasitoids from 26 pupae of $P$. chrysostoma. Aphaereta sp. was collected, with several individuals emerging from the same pupae.
\end{abstract}

Key words: Hymenoptera, Diptera, parasitoid, wood, Itumbiara, Goiás.

\section{RESUMO}

\section{Aphaereta sp. (Hymenoptera, Braconidae, Alysiinae) como inimigo natural de Peckia} chrysostoma (Wiedemann) (Diptera: Sarcophagidae), no Brasil

Este trabalho relata a primeira ocorrência do parasitóide Aphaereta sp. coletado de pupas de Peckia chrysostoma, utilizando-se armadilhas com isca de peixe cru em área de mata da Faculdade de Agronomia em Itumbiara, Goiás, de março a setembro de 2001. Foram coletados um total de 362 espécimes de parasitóides em 26 pupas de $P$. chrysostoma. Aphaereta sp. apresentou-se como gregária, emergindo vários indivíduos de uma mesma pupa.

Palavras-chave: Hymenoptera, Diptera, parasitóide mata, Itumbiara, Goiás.

\section{INTRODUCTION}

Sarcophagidae are viviparous insects or, rarely, ovoviviparous (Lopes \& Leite, 1989; Shewell, 1987). Six hundred species of Sarcophagidae from Neotropical region have been recognized. On the other hand, this dipterous carries relevant importance in public health, for being the vehicle of pathogenic micro-organism to human beings (Greenberg, 1971; Marchenko, 1985).

Peckia chrysostoma (Wiedemann) (Diptera: Sarcphagidae), a neotropic and sinantropic species is widely spread (Ferraz, 1995). These species demonstrated in Rio de Janeiro, have a preference for enviroments inhabited by men and the bait that most attracted it was raw fish (D'Almeida, 1984).

The superfamily Ichneumonoidea parasitize mainly larvae and pupae of holometabolous insects. Braconidae is the second largest family of Hymenoptera, with at least 40,000 species. Most species of Braconidae are endoparasitic koinobionts, although a large number are idiobiont ectoparasitoids. Most of the subfamily Alysiinae are solitary koinobionts and all are endoparasitic on Diptera Cyclorrhapha larvae (Gauld \& Bolton, 1988). 
The fly control using fly-spray always ends up in selecting resistant populations, being just a palliative. Mendes \& Linhares (1993) believe in the need of researching new methods concerning fly control; and as a possibility to control these insects, some natural regulators can be used, such as parasitoids which are responsible for the reduction of synanthropic fly populations. The aim of this paper is to relate the new host for the Aphaereta sp. species in Brazil.

The study was conducted at the wood of the Agronomy college (Faculdade de Agronomia) setlled in the city of Itumbiara GO $\left(18^{\circ} 25^{\prime} \mathrm{S}\right.$ $49^{\circ} 13^{\prime} \mathrm{W}$ ), Brazil (Fig. 1). The flies were attracted to the traps made of dark dull cans, measuring 19 $\mathrm{cm}$ of height and $9 \mathrm{~cm}$ diameter, with two openings like blinders, located in the third inferior part to allow the entrance of the flies. The upper part the cans were coupled with nylon funnels, opened at the bottom, base pointing down and wrapped with plastic bags, so when removed would make possible the collection of flies and parasitoids. The following items were used as fish baits placed inside the cans, over a layer of land (Fig. 2). Five traps were used and they were hanged in trees one meter from the ground, two meters apart from each other. The collected insects were taken to the laboratory, sacrificed with ethyl ether and kept in $70 \%$ alcohol for further identification. The content of the traps was placed in plastic containers having a layer of sand to be used as a substratum of larvae pupae. After remaining in the field for 15 days, the sand was sifted and from this sand was extracted the pupae which were individually placed in gelatine capsules (00 number) to obtain flies and/or the parasitoids.

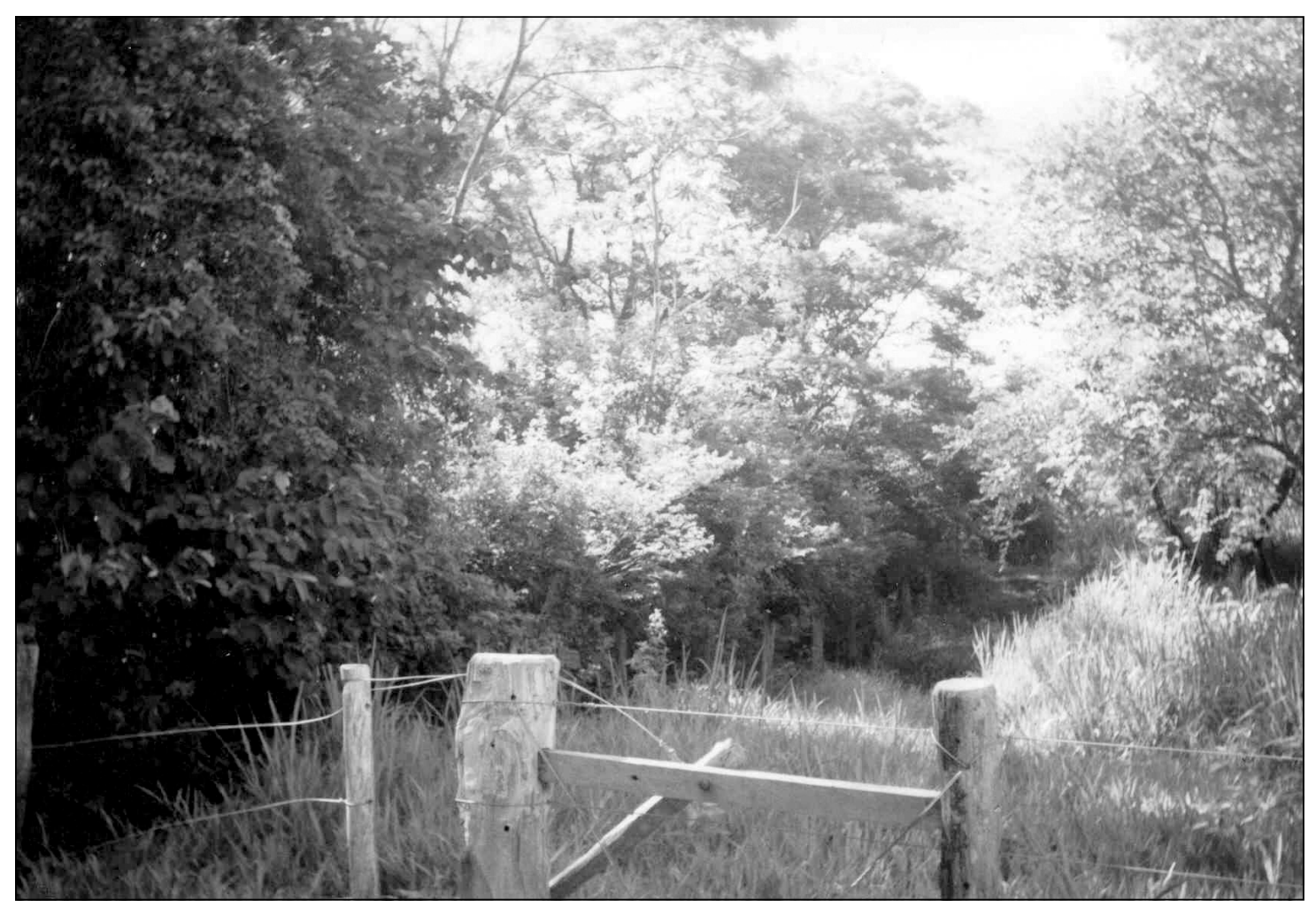

Fig. 1 - General aspect of the trap to collect parasitoids. 


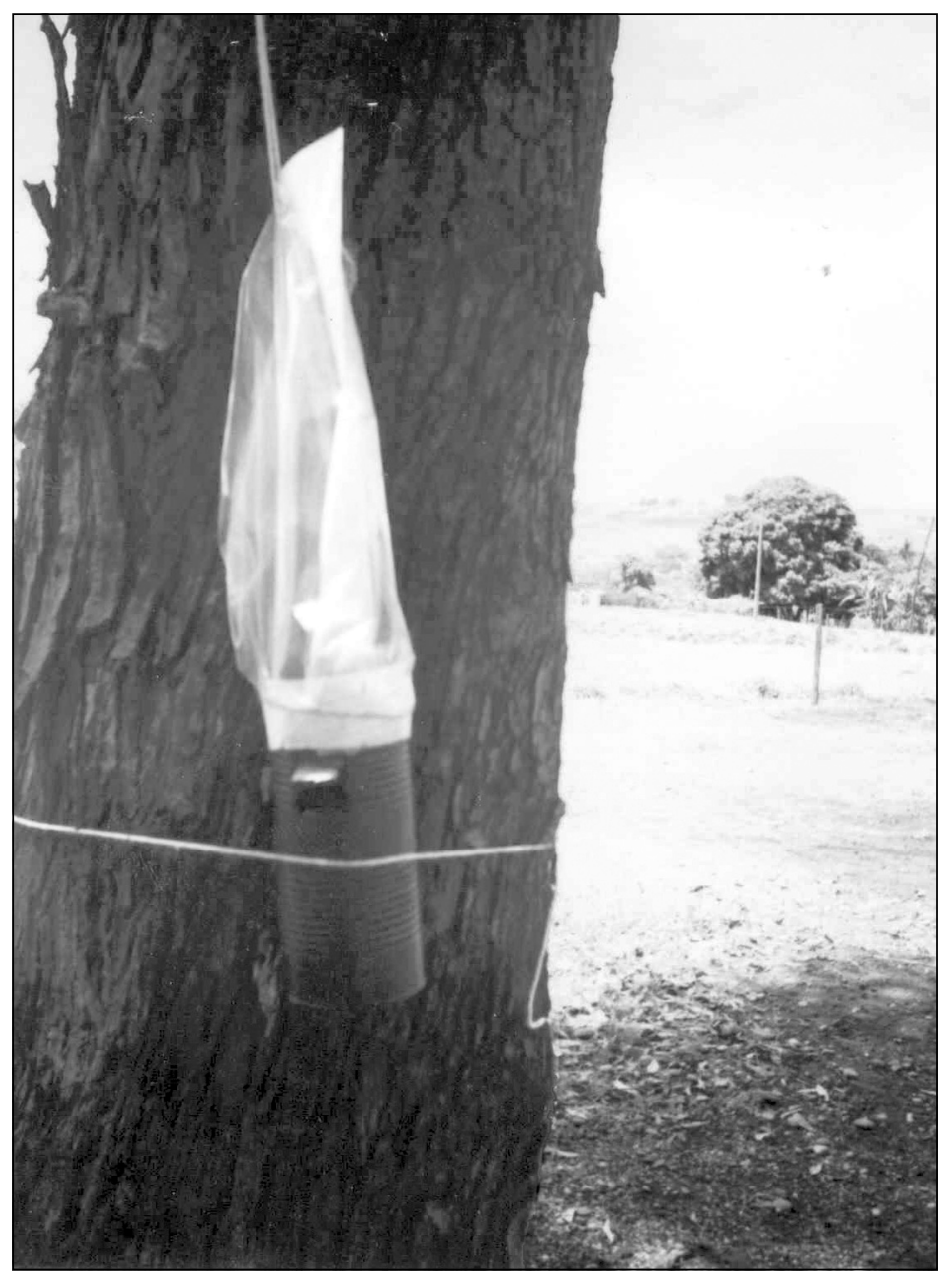

Fig. 2 - General aspect of the wood of the Agronomy college (Faculdade de Agronomia) situated in Itumbiara, Goiás.

During the period from March to September 2001, 374 specimes of Aphaereta sp. (Hymenoptera: Braconidae) were collected in 26 pupae of Peckia chrysostoma (Diptera: Sarcophagidae). From the first to twelfh pupae were found $8,10,22,27,28$, $29,31,31,40,42$, 47, and 60 specimens, respectively. Aphaereta sp. was gregarious, with several individuals emerging from the same pupary, a poliembrionary is considered very ordinary. Figg et al. (1993) it was observed that a lot of Aphaereta species are gragarious. The species Aphaereta sp. occurs almost everywhere around the world and lives associated to sinatropic dipterous and other Diptera, emerging from their pupa shell.
Watts \& Combs (1977) point out Aphaereta sp. as an important component in cattle excrements attacking pupas of Haematobia irritans L. (Diptera: Muscidae) in the Mississipi estate (USA). In fact the Aphaereta sp. has attracted the attention of a large number of investigators as a potential biological control, because of its wide distribution and host range (Whistlecraft et al., 1984). This specie was dipterous parasitoid, it developed in bovine liver in typical wood areas in the state of Goiás (Marchiori et al., 2000). Therefore, this is the first register of Aphaereta sp. in pupae P. chrysostoma in Brazil. The results obtained from this research allow us to stretch the occurrence of Aphaereta sp. on a new host. 


\section{REFERENCES}

D'ALMEIDA, J. M., 1984, Sinantropia da Sarcophagidae (Diptera) na região metropolitana do Estado do Rio de Janeiro. Arq. Univ. Fed. Rur. Rio de J., 7: 101-110.

FERRAZ, M. V., 1995, Larval and pupal periods of Peckia chrysostoma and Adiscochaeta ingens (Diptera: Sarcophagidae) reared under laboratory conditions. Mem. Inst. Oswaldo Cruz, 90: 611-614.

FIGG, D. E., HALL, R. D. \& THOMAS, G. D., 1993, Host range and eclosion success of the parasite Aphaereta pallipes (Hymenoptera: Braconidae) among dungbreeding Diptera in Central Missouri. Environ. Entomol. 12: $993-995$

GAULD, I. D. \& BOLTON, B., 1988, The Hymenoptera. Oxford Univ. Press, 331p.

GREENBERG, B., 1971, Flies and disease - ecology, classification and biotic association. Princeton Univ. Press, New Jersey, 856p.

LOPES, H. S. \& LEITE, A. C. R., 1989, Morphology of the egg of Sarcodexia lambens (Diptera: Sarcophagidae). Mem. Inst. Oswaldo Cruz, 84: 497-500.
MARCHENKO, M. I., 1985, Characteristic of development of the fly Chrysomya albiceps (Wd.) (Diptera, Calliphoridae). Entomol. Obozr., 64: 79-84.

MARCHIORI, C. H., CASTRO, M. E. V., PAIVA, T. C. G., TEIXEIRA, F. F. \& SILVA, C. G., 2000, Dipteros muscóides de importãncia médica e veterinária e seus parasitóides em Goiás. Arq. Bras. Med. Vet. Zootec., 52: 350-353.

MENDES, J. \& LINHARES, A. X., 1993, Atratividade por iscas, sazonalidade e desenvolvimento ovariano em várias espécies de Muscidae (Diptera). Rev. Bras. Ent., 37: 289297.

SHEWELL, G. E., 1987, Sarcophagidae. Research Branch Agriculture Canada, 1186p.

WATTS, K. J. \& COMBS, Jr. L., 1977, Parasites of Haematobia irritans and Other Flies Breeding in Bovine Feces in Northeast Mississippi. Environ. Entomol., 6: 823-826.

WHISTLECRAFT, J. W., HARRIS, C. R., TOMLIM, A. D. \& TOLMAN, J. H., 1984, Mass rearing technique for a braconid parasite, Aphaereta pallipes (Say) (Hymenoptera: Braconidae). J. Econ. Entomol., 77: 814-816. 